\title{
Time-varying Integration of Stock Markets from Global and Regional Perspective in Asia-Pacific
}

\author{
Hayun Kusumah ${ }^{1 *}$, Marwan Asri², Kusdhianto Setiawan², Bowo Setiyono ${ }^{2}$ \\ ${ }^{1}$ Doctoral Student at Faculty of Economics and Business, Universitas Gadjah Mada, Indonesia \\ 2Department of Management, Faculty of Economics and Business, Universitas Gadjah Mada, \\ Indonesia \\ *Corresponding Author: hayun.kusumah@mail.ugm.ac.id
}

\begin{abstract}
This study investigates the time-varying integration of stock markets from a global and regional perspective, the consequences of two major global financial crises, i.e., the Asian Financial Crisis and the subprime mortgage, and the Crisis triggered by COVID-19. We contribute to the growing amount of literature on market integration, especially on the role of regional to global market integration. Although regional integration encourages an acceleration of global integration, the effect of a regional factor is not uniform among regions. It is important to understand regional to global market integration and the consequences during the crises. This study employs time-series data from economic territories based on the Morgan Stanley Capital International (MSCI) Asia-Pacific classification. It introduces an alternative measurement of time-varying integration by considering the correlation of regional and global markets using a simple international model, equivalent to the capital asset pricing model (CAPM). The result shows that the market integrations are time-varying both globally and regionally. The domestic markets are affected by the global market and its regional market, as the role of a regional market emerges during the financial crisis period. We find the different responses of stock markets during the Covid-19 period as a dominant factor to exacerbate the market return globally. In the long run, the upward trend for the regional market integration in both developed and emerging markets is inherent to the global market integration.
\end{abstract}

Keywords: capital asset pricing model; covid-19; global financial crisis; market integration

\section{INTRODUCTION}

Market integration is an essential subject of study in international finance due to liberalization and globalization, especially in emerging financial markets. The removal of trade barriers and capital control has gradually led to rapid international trade developments in commodities, services, and financial assets; so, the world's economic and financial systems are increasingly integrated. International organizations such as the IMF, the World Bank, and the World Trade Organization (WTO) have issued various policy 
frameworks for international finance and trade, thereby accelerating global integration. The WTO was established in 1995 and replaced the General Agreement on Tariffs and Trade (GATT), which was established in 1947 to encourage countries to gradually reduce their trade barriers and capital controls, especially in emerging countries. They also have more concern for the coherence and harmonization of the global economy, especially regarding the overlapping functions of the WTO, the World Bank, and the IMF1.

Regional agreements and cooperation have caused an increase in cross-border trade, thus encouraging globalization's acceleration, but the wave of globalization is not uniform among regions. For example, the agreement and cooperation between the European countries through the single market and currency mechanism has led to increased market integration in all the member countries (see, P. L. Chelley-Steeley et al., 1998; Fratzscher, 2002; Lee \& Kim, 2020). Likewise, in Asia, America, and other regions, various bilateral and multilateral agreements have also developed. Discriminatory trade policies based on the geographical area are a characteristic of regional integration agreements, such as free trade areas formed to reduce trade tariffs between the members and provide autonomy when setting trade tariffs with non-members. The Asia-Pacific region is one of the regions with rapid economic development that also seeks to establish agreements with a free trade framework, such as that of the ASEAN Free Trade Area (AFTA), which was expanded to become the ASEAN + China Free Trade Area (AC-FTA), the ASEAN Economic Community (AEC), and the Asia-Pacific Trade Agreement (APTA). These agreements should enable the acceleration of regional integration; therefore, the effect of any regional factors needs to be considered under the global market integration.

This study investigates the time-varying integration of stock markets from a global and regional perspective. Although regional integration encourages the acceleration of global integration, regional integration may differ among the regions. We also examine the consequence of the Asian financial crisis (1997/1998), the subprime mortgage (2007/2009), and the novel coronavirus (Covid-19) pandemic to see whether they had a significant effect on the market return. This study focuses on these issues to understand the dynamics of market integration, both globally and regionally, and the consequences of the global financial crises, including the crisis triggered by Covid-19.

This study contributes to the existing literature in various ways. First, we contribute to the growing amount of literature on market integration, especially on regional to global market integration, and their relationship with two major global financial crises (i.e., the Asian financial crisis and the subprime mortgage crisis), the crisis triggered by Covid-19. The latter crisis is different; World Health Organization (WHO) declared it a pandemic on March 11, 2020, with a cumulative confirmed case of 118,319 and 4,292 deaths globally (WHO, 2020). Since its start in China in early 2020, the Covid-19 is causing a huge impact on the real economy worldwide. To the best of our knowledge, although this issue has been studied extensively, it has not been widely studied with considered the role of regional to global market integration in a comprehensive perspective. Most of the previous studies about market integration only focus on global integration using a global market proxy (e.g., Billio et al., 2017; Boamah, 2017; Caporale et al., 2021; Lehkonen, 2015) and/or among domestic markets in a region (Al Nasser \& Hajilee, 2016; Boamah, 2017; Chevallier et al., 2018; Muharam et al., 2020; Robiyanto, 2018a; Sehgal et al., 2018). In general, they found that the global market integration is dynamics or time-varying for any reason caused it. In the case of the regional market, there are inconclusive results, especially regional market integration. Some studies found an increased integration 
between markets in a region (M. Arouri et al., 2013; Chevallier et al., 2018; Lee \& Kim, 2020; Robiyanto, 2018a; Sehgal et al., 2018), but other studies found some markets were not or less integrated with a region (Chevallier et al., 2018; Jeon et al., 2006; Muharam et al., 2020). Most findings show the degree of global market integration exceeds their degree of integration with themselves or the regional market integration (Boamah, 2017; Caporale et al., 2021) but less explanation about the role of regional to global market integration.

Second, we extend an alternative methodology to measure an integration level, which will capture the time-varying integration level, both globally and regionally, by considering the correlation of global and regional markets. This measurement is based on price indicator and simple international model equivalent to the capital asset pricing model (CAPM); therefore, they give a direct measurement and direct interpretation with a robust asset pricing model. We also consider the correlation of global and regional markets using proxies of the Morgan Stanley Capital International (MSCI) World and Asia-Pacific as a system equation because the regional market integration is a part of the global market integration. This methodology is based on the price of stock markets as a proxy of economic integration, widely using the argument that unrestricted international capital flows will lead to equal rates of return across countries. In addition, the performance of a country's stock market has a strong relationship with its economic performance, so the usage of stock market integration is expected to show the dynamics of its economic integration (e.g., Akbari et al., 2020; R. F. Engle et al., 2013; Paramati et al., 2016; Setiawan, 2012; Yu et al., 2010).

The rest of this article is organized as follows. Section 2 presents some reviews about market integration and global financial crises. Section 3 introduces the model and empirical methodology. Section 4 presents the data and discusses our major empirical results, and the conclusions and suggestions are in Sections 5 and 6.

\section{LITERATURE REVIEW}

Market integration refers to the fact that there has been an increase in trade and financial market internationally, strengthening the co-movement among countries' domestic markets. Capital mobility and free trade have driven the globalization process, which has led to increasing integration in terms of the real or financial markets. Karolyi and Stulz (2002) defined an integrated market as one that applies the law of one price, in which assets have the same price wherever they are traded. Investors should earn the same expected returns on similar assets in different domestic markets in such a market. However, markets globally are interconnected but not perfectly integrated or segmented, so they are partially integrated (M. E. H. Arouri et al., 2012; Bekaert \& Harvey, 1995; Carrieri et al., 2007). Why are these markets partially integrated? Arouri et al. (2012) argued that some investors could not access all the international assets due to direct and indirect barriers.

Consequently, a global market portfolio becomes inefficient. Bekaert (1995), Bekaert and Harvey (2003), and Lehkonen (2015) attempted to explain the differences in integration and argued that there are three different barriers to market integration: 1) A legal barrier, because of the differences to the legal status of foreign and domestic investors for taxation and policies creating a restriction on the movement of capital; 2) An 
information barrier, because of differences in the access to information, accounting standards, and investor protection; and 3) Emerging market-specific risks, such as political, economic policy, and liquidity risks that are unfavorable toward foreign investment. In the long run, market integration is time-varying and takes several years with occasional reversals has been generally accepted (M. E. H. Arouri et al., 2012; Bekaert et al., 2003, 2011; Carrieri et al., 2006; Chevallier et al., 2018; Pukthuanthong \& Roll, 2009; Sehgal et al., 2018).

Financial market theories suggest that in an integrated market, the law of one price applies where assets have the same price at all locations. If investors bear global and local risks in their portfolios, then only the global risks are priced because the local risks have diversified internationally. Most domestic markets are supposed to be between the two extremes market of perfect market integration and segmentation. This condition is partially integrated (Karolyi \& Stulz, 2002; Kearney \& Lucey, 2004; M. Arouri et al., 2013). From a global and regional perspective, the expected return should be affected by a combination of local, regional, and global risks.

Some empirical studies into regional market integration have shown inconclusive results. Jeon et al. (2006) studied market integration in East Asia and described that the regional market seems to give no strong signs to the domestic markets, but it was better integrated with the global market. Muharam et al. (2020) investigated stock markets integration in Asia from 1999 to 2018. They found evidence that only the stock markets of Singapore, Hong Kong, Japan, Taiwan, Thailand, and South Korea tended to integrate, while those in Indonesia, the Philippines, and Malaysia did not. Chevallier et al. (2018) studied the market integration among Pacific Basin countries from 1993 to 2014. The ASEAN markets have become more integrated to the USA than other developed countries in East Asia (Japan, South Korea, and Taiwan).

In contrast, Arouri et al. (2013) studied in some regions from 1988 to 2012 and described that total risk premiums are mostly affected by regional residual risk factors that reflect regional events. However, in the last period, emerging market regions have become less segmented because liberalization has caused an increasing the exposure of global factors. Caporale et al. (2021) investigated the global and regional financial integration in emerging Asia from 2000 to 2016 using MSCI Asia and Japan's stock market as the proxy of regional market. They found that in emerging Asia, regional integration is stronger than global integration during the post-2008 crisis period, with Hong Kong, Taiwan, and Thailand are the most regionally integrated markets. Robiyanto (2018a) found an increasing integration of Indonesia's stock market to the other domestic market of ASEAN and the World. Sehgal et al. (2018) also confirmed the regional integration of ASEAN+6 is strengthening over time from 1999 to 2015.

Previous studies into increased market integration also show inconclusive results. Increased market integration has the opposite implications; although it has some advantages, it also has several drawbacks. Most evidence for increased markets integration, in general, shows they have direct and indirect advantages. The direct advantage is more integrated market should lead to a lower cost of capital, increased investment opportunities, increased savings, and enhanced economic growth through international risk sharing (Bekaert \& Harvey, 2003; Carrieri et al., 2007). The indirect implication is expected to encourage the development of domestic markets, improve corporate and public governance, lead to efficiency among domestic firms that are subject 
to international competition, and discipline on macroeconomic policies (Kose et al., 2009). For investors, it provides an opportunity to diversify their portfolio internationally. They can easily buy and sell financial assets in a large number of markets, which makes it possible for them to find attractive opportunities and increase their long-term returns on investment. However, international diversification has a legitimate reason, as there are gains to be made from it. Increased market integration also leads to strengthening the correlation of international assets, causing the benefit of diversification tends to decline. This argument is well known, and is based on the modern portfolio theory, which rely on the seminal work of Harry Markowitz (1952).

The advantage of integrated markets is questioned, especially when global financial crises occur because the highly interconnected markets will accelerate and propagate shocks across the markets. A more globally integrated country will be more vulnerable to shocks due to the high interconnectivity among its markets, which may lead to the spread of a crisis among the global markets (Berger \& Pukthuanthong, 2012; Pukthuanthong \& Roll, 2009). Some empirical studies during crisis periods have shown the dynamics of market integration. Caporalle et al. (2021) used the sub-period analysis to show that global integration is stronger during the pre-2008 crisis. Narayan et al. (2014) investigated stock market integration in emerging Asia from 2001 to 2012 and found stronger market integration during the 2007-2009 crisis. Lehkonen (2015) found the different trends of integration between emerging and developed markets during the crisis. The market integration decreased during the global financial crisis for developed markets, but it increased slightly for emerging markets.

The recent crisis is triggered by Covid-19, which was declared as a pandemic by the World Health Organization (WHO) on March 11, 2020 (WHO, 2020). The crisis starts from the Chinese city of Wuhan in early 2020; since declared as a pandemic until the end of May 2021, the cumulative of confirmed cases and death increased from 118,319 to $169,597,415(143,239 \%)$ and 4,292 to 3,530,582 (82,160\%) globally (WHO, 2020, 2021). Most countries worldwide respond to the pandemic in various ways, such as partial or complete lockdown, social distancing, investments in handling Covid-19, etc. There is no rule book, policy prescriptions, or models, especially in economics, that the government can use. This pandemic is causing global economic damage of destructive unprecedented (Ashraf, 2020; Goodell, 2020). Although the stock market is not the only indicator, it's a significant indicator to understand the market reaction due to this pandemic, which can trigger a global financial crisis, and it's still being debated. Mazur et al. (2021) investigated the US stock market performance during the Covid-19 and found the firms react in a variety of different ways. The stock of natural gas, food, healthcare, and software earned high positive returns, whereas real estate, entertainment, and hospitality sectors fell dramatically in the petroleum, real estate, entertainment, and hospitality sectors. Harjoto et al. (2021) found that the Covid- 19 caused a negative shock to the global stock markets, especially in emerging markets and small firms. Related to the results, Ashraf (2020) studied using 64 countries from January 22, 2020, to April 17, 2020, and found that stock market returns declined in response to local Covid-19 outbreaks. Most of them showed that the world's stock markets reacted to the Covid-19 pandemic with unprecedented volatility and strong negative returns. 


\section{METHOD, DATA, AND ANALYSIS}

\section{Samples and Data}

The samples in this study are the economic territory of the Asia-Pacific region, which is one of the regions with rapid economic development and had a market capitalization of $74 \%$ of the world in $2017^{2}$. There are also some regional agreements for cooperation, such as the AFTA, AC-FTA, AEC, and APTA, which encourage regional integration, which is the issue for this study. The classification of the sample is based on the Morgan Stanley Capital International (MSCI) for Asia-Pacific. It consists of a) developed markets: Australia (AUS), Hong Kong (HKG), Japan (JPN), New Zealand (NZL), Singapore (SGP); b) emerging markets: China (CHN), India (IND), Indonesia (IDN), South Korea (KOR), Malaysia (MYS), Pakistan (PAK), the Philippines (PHL), Taiwan (TWN), and Thailand (THA). This study also includes the United States of America (USA). However, it is not an official MSCI Asia-Pacific classification because it is a developed country with the world's largest economy and has the longest tradition of free capital mobility. It's also as the investor's perspective of the USA to examine market integration, both globally and regionally. This sample is expected to represent global and regional markets, as well as developed and emerging markets.

We used daily data of the domestic market indices in their local currency, the MSCI AC World Index, MSCI AC Asia Pacific Index, and 3-months US T- Bills (in USD) from Thomson Reuters for the period from January 1991 to May 2021 (see, Appendix D). We converted the domestic market indices from their local currency into a common currency, USD. We mitigated the effect of time-zone differences in the daily data with a one-day lag to adjust for the USA. We used the MSCI AC World Index and MSCI AC Asia-Pacific Index as proxies for the global market (GLO) and regional market (REG), and 3-months US T- Bills as a risk-free, which is considered almost free from any default-risk and have the shortest period, so that it cannot be re-invested.

\section{Measurement of Time-Varying Market Integration}

To estimate the level of the various market integration over time both globally and regionally, we derive an equation that can be regarded as an augmented international equivalent of the capital asset pricing model (CAPM) developed by Sharpe (1964), Lintner (1965), and Mossin (1966) with the following equation 1 and 2.

$$
\begin{gathered}
R_{i}-R_{f}=\beta\left(R_{m}-R_{f}\right) \\
\beta=\frac{\operatorname{Cov}\left(R_{i}, R_{m}\right)}{\operatorname{Var}\left(R_{m}\right)}
\end{gathered}
$$

where $R_{i}$ is the return of risky asset $i, R_{f}$ is the risk-free return, $R_{m}$ is the return of the market portfolio, and $\beta$ or beta is the parameter of market integration as the contemporaneous correlation of $R_{i}$ and $R_{m}$. We use the domestic market as a national single risky asset and the global and regional market as a broader market in the international context. To measure time-varying beta, we use the conditional CAPM and Baba-Engle-Kraft-Kroner (BEKK) GARCH to capture the correlations (see Choudhry et al., 2010; Setiawan, 2014) with mean-equation 3, 4, and 5.

$$
\begin{aligned}
& R_{i_{t}}=\alpha_{1}+\varepsilon_{1 t} \\
& R_{r_{t}}=\alpha_{2}+\varepsilon_{2}
\end{aligned}
$$




$$
R_{g_{t}}=\alpha_{3}+\varepsilon_{3 t}
$$

where $R_{i}$ is the return of domestic market $i, R_{r}$ is the return of the regional market, $R_{g}$ is the return of the global market, and $E\left(\varepsilon_{1_{t}}, \varepsilon_{2_{t}}, \varepsilon_{3_{t}}\right) \neq 0$. The residuals are used to estimate the conditional variance-covariance matrix of $\boldsymbol{H}_{t}$ which is represented as the following equation:

$$
\boldsymbol{H}_{t}=\left[\begin{array}{ccc}
h_{i i_{t}} & h_{i g_{t}} & h_{i r_{t}} \\
- & h_{g g_{t}} & h_{g r_{t}} \\
- & - & h_{r r_{t}}
\end{array}\right]
$$

where $\mathrm{h}_{i i}, \mathrm{~h}_{g g}, \mathrm{~h}_{r r}$ are the conditional variances of the domestic, global, and regional market; and $\mathrm{h}_{i g}, \mathrm{~h}_{i r}, \mathrm{~h}_{g r}$ are the conditional covariance between the domestic-global, domestic-regional, and global-regional market. The level of market integration is estimated from the correlation between the domestic market and the global or regional market that are represented as global beta $\left(\beta_{g}\right)$ and regional beta $\left(\beta_{r}\right)$. The time-varying betas are estimated based on the conditional variance-covariance matrix of $\boldsymbol{H}_{t}$ with the following equations:

$$
\begin{gathered}
\beta_{g_{t}}=\frac{h_{i g_{t}}}{h_{g g_{t}}} \\
\beta_{r_{t}}=\frac{h_{i r_{t}}}{h_{r r_{t}}}
\end{gathered}
$$

We use the BEKK-GARCH method followed what had been done by Billio et al. (2017), Choudhry et al. (2010), and Setiawan (2014) based on the conditional CAPM in which the beta varies over time due to the market's conditional variance, and the conditional covariance between the asset's return and the market's return. The BEKK model is sufficiently general to use, which include all positive definite diagonal representations in the variance-covariance matrix $\left(H_{t}\right)$. The model implies that only the magnitude of past returns innovations is important in determining current conditional variances and covariances, which is quite in-line with the conditional CAPM. For the robustness test, the market integration is also estimated using the DCC-GARCH by Engle (2002) to accommodate the dynamic correlation between the domestic, global, and regional market. The DCC model calculates current correlation between variables as a function of past realizations of volatility within the variables as well as the correlations between the variables which is used to estimate the volatility of correlations. The usage of DCC model also followed what had been done by previous studies such as Billio et al. (2017) and Robiyanto (2018a, 2018b).

\section{Market Integration and Global Financial Crisis}

Some previous studies have been taken into consideration to define the period of the global financial crises. Our main interest lies in the Asian financial Crisis of 1997 to 1998, the subprime mortgage crisis of 2007 to 2009, and the crisis triggered by Covid-19. For the Asian financial crisis, we define the start as being when the market in Hong Kong crashed in October 1997, and the end of this crisis period is defined as being in December 1998. We define the beginning of the subprime mortgage crisis using two different dates. The first was when the initial fall of the stock market occurred, due to a liquidity crisis, in August 2007, and the second was the collapse of Lehman Brothers during September 
2008. The end of this crisis period was determined to be during June 2009, based on data from the National Bureau of Economic Research (NBER), which considers that date to be the end of the recession in the USA. Meanwhile, the crisis triggered by Covid-19 defines the start as being when the World Health Organization (WHO) declared COVID-19 as a pandemic on March 11, 2020 (Ashraf, 2020; Harjoto et al., 2021; Phan \& Narayan, 2020; WHO, 2020).

The effect of market integration during a crisis and non-crisis periods is estimated using OLS, and a model is derived from the CAPM using the following equations:

$$
\begin{gathered}
R_{i t}-R_{f t}=a+b \hat{\beta}_{i t}+\varepsilon_{i t} \\
R_{i t}-R_{f t}=a_{1}+b_{1} \hat{\beta}_{i t}+b_{2} \text { Crisis }_{t}+b_{3} \text { Crisis }_{t} * \hat{\beta}_{i t}+\varepsilon_{i t}
\end{gathered}
$$

where $R_{i}$ is the return of stock market $i, R_{f}$ is the risk-free return, $\hat{\beta}_{i}$ Is the estimated beta of equation (7) or (8) for global and regional, and crisis is a dummy variable with a value of 1 for crisis and 0 for the non-crisis period?

\section{RESULTS AND DISCUSSION}

\section{Summary Statistics}

Summary statistics are presented in Table 1 for the total available data of each sample. The return data for each sample were checked to detect the presence of errors. We dropped one item of data from China dated May 21, 1992, as it has shown an extreme daily return of $105 \%$, which was treated as an outlier. Table 1 reports the averages of the domestic market returns are between $0.0136 \%$ and $0.0516 \%$, with standard deviations between $1.0888 \%$ to $2.0656 \%$. The averages of the developed and emerging market return are $0.0283 \%$ and $0.0339 \%$, with standard deviations of $1.2695 \%$ and $1.7135 \%$. The emerging markets have greater volatility and return, which means the risk and return trade-off is applied. It shows the differences in the domestic market returns that attract investors to diversify their portfolios internationally, particularly by going into emerging markets for higher returns and higher risks.

Meanwhile, the global and regional market returns are $0.0280 \%$ and $0.0174 \%$, with standard deviations of $0.9405 \%$ and $1.1539 \%$. It shows that the diversification into the global market is more attractive with higher returns and lower risks than the regional markets. Investors should be more interested in diversifying their portfolios globally, offering better returns and less risk. If investors have an attitude of risk-seeking, they should be more interested in diversifying their portfolios globally, especially in emerging markets.

Table 2 reports the unconditional correlation among the markets (i.e., domestic, regional, and global markets). The correlation among the domestic markets is between 0.0361 and 0.6259, with the lowest correlation between China and Pakistan, while the highest correlation is between Australia and New Zealand. China and Pakistan have the lowest economic relationship, while Australia and New Zealand have a high economic relationship or are more integrated.

The average correlation between the developed and emerging markets is 0.4100 and 0.2038 , which shows the developed markets are more correlated than emerging markets. The developed markets are also more correlated to the global markets than the emerging markets, with values of 0.3584 and 0.1970 (on average). Investors should consider these 
correlations because the higher correlation tends to reduce the diversification benefit. Meanwhile, the correlation between the global and regional markets (with a value of 0.4887) is important and significant enough to be considered to analyze the market integration between domestic and global markets in this study.

\section{Time-Varying Market Integration}

The stock market integration is estimated using the parameter of time-varying beta described in the research method section. The global beta (i.e., the global market integration) and the regional beta (i.e., the regional market integration) are estimated from equations (7) and (8) using the BEKK-GARCH method. The estimation results of these market integrations are presented in Figures 1 and 2; the descriptive statistics and univariate tests for equality are presented in Table 3 . The time-varying integration of stock markets for all the domestic markets or grouped by developed and emerging markets, both globally and regionally, is presented in Figure 3. The robustness test is carried out using the DCC-GARCH method to estimate the global and regional market integration, which captures the dynamic correlation between the domestic, global, and regional markets. The result is presented in Appendix A.

Table 3 reports that global and regional market integration averages in the developed markets are 0.4568 and 0.5961 with standard deviations of 0.3391 and 0.2484 . In emerging markets, global and regional market integration averages are 0.2839 and 0.3757 with standard deviations of 0.4326 and 0.3322 . It shows that the developed markets are more integrated to the global and regional markets, which have lower volatility than the emerging markets. However, both developed and emerging markets are more integrated into the regional market than the global market with 0.4638 and 0.3530 (average). The Asia-Pacific region means that the domestic markets are more correlated economically in the region than to a broader market.

The robustness test (Appendix A) reports that the averages of global and regional market integration in the developed markets are 0.4989 and 0.6328 with standard deviations of 0.2596 and 0.2141 , and the emerging markets are 0.35140 .4784 with standard deviations of 0.2959 and 0.2990 . Although this result has differences in the descriptive statistics, this finding is consistent with the previous analysis that the developed markets are more integrated to both global and regional markets than the emerging markets; and both developed and emerging markets are more integrated into the regional market, which has lower volatility than the emerging markets. The developed and emerging markets are more integrated into the regional market than the global market, with values of 0.5401 and 0.4104 (on average). It also confirms that the domestic market in the Asia-Pacific region is more correlated economically in the region. 
Table 1. Summary Statistics of Market Returns

\begin{tabular}{|c|c|c|c|c|c|c|c|c|c|c|c|c|c|c|c|c|c|}
\hline & \multicolumn{2}{|c|}{$\begin{array}{c}\text { Global and } \\
\text { Regional } \\
\text { Market }\end{array}$} & \multicolumn{6}{|c|}{ Developed Markets } & \multicolumn{9}{|c|}{ Emerging Markets } \\
\hline & GLO & REG & USA & AUS & HKG & JPN & NZL & SGP & $\mathrm{CHN}$ & IDN & IND & KOR & MYS & PAK & PHL & THA & TWN \\
\hline Mean & 0.0003 & 0.0002 & 0.0003 & 0.0003 & 0.0004 & 0.0001 & 0.0003 & 0.0002 & 0.0005 & 0.0003 & 0.0005 & 0.0003 & 0.0002 & 0.0004 & 0.0003 & 0.0002 & 0.0003 \\
\hline Median & 0.0006 & 0.0004 & 0.0003 & 0.0005 & 0.0001 & 0.0001 & 0.0005 & 0.0002 & 0.0000 & 0.0002 & 0.0004 & 0.0000 & 0.0000 & 0.0002 & 0.0000 & 0.0003 & 0.0001 \\
\hline Maximum & 0.0952 & 0.1053 & 0.1222 & 0.1388 & 0.1882 & 0.1359 & 0.0932 & 0.1425 & 0.3346 & 0.2508 & 0.2340 & 0.3244 & 0.2808 & 0.1361 & 0.2402 & 0.1646 & 0.0948 \\
\hline Minimum & -0.0991 & -0.0863 & -0.1183 & -0.1406 & -0.1363 & -0.1112 & -0.1076 & -0.1022 & -0.3131 & -0.3283 & -0.1654 & -0.1866 & -0.2146 & -0.1238 & -0.1419 & -0.1451 & -0.0981 \\
\hline Std. Dev. & 0.0094 & 0.0115 & 0.0110 & 0.0126 & 0.0152 & 0.0138 & 0.0109 & 0.0126 & 0.0207 & 0.0204 & 0.0170 & 0.0203 & 0.0139 & 0.0149 & 0.0155 & 0.0163 & 0.0152 \\
\hline Skewness & -0.4290 & -0.0125 & -0.3564 & -0.4463 & 0.2610 & 0.1865 & -0.4408 & 0.2242 & 1.3345 & -0.3639 & 0.2996 & 0.7744 & 1.7808 & -0.1957 & 0.4770 & 0.1926 & -0.0644 \\
\hline Kurtosis & 14.6698 & 8.3840 & 16.9272 & 13.1844 & 13.9338 & 8.7835 & 9.6460 & 12.7354 & 40.0389 & 39.2367 & 16.3965 & 24.5055 & 58.6551 & 10.2015 & 18.9037 & 11.7466 & 6.7186 \\
\hline Jarque-Bera & 45,264 & 9,583 & 64,290 & 34,552 & 39,611 & 11,104 & 14,859 & 31,398 & 455,876 & 434,263 & 59,447 & 153,683 & $1.0 \mathrm{E}+06$ & 17,195 & 83,915 & 25,340 & 4,577 \\
\hline Probability & 0.0000 & 0.0000 & 0.0000 & 0.0000 & 0.0000 & 0.0000 & 0.0000 & 0.0000 & 0.0000 & 0.0000 & 0.0000 & 0.0000 & 0.0000 & 0.0000 & 0.0000 & 0.0000 & 0.0000 \\
\hline Sum & 2.2232 & 1.3809 & 2.6519 & 2.3833 & 3.1682 & 1.0815 & 2.2831 & 1.9131 & 4.0927 & 2.2969 & 3.6672 & 2.7225 & 1.4781 & 3.3283 & 2.6950 & 1.7117 & 2.2082 \\
\hline Sum Sq. Dev. & 0.7018 & 1.0562 & 0.9666 & 1.2594 & 1.8365 & 1.5185 & 0.9405 & 1.2579 & 3.3849 & 3.2972 & 2.2990 & 3.2762 & 1.5394 & 1.7555 & 1.9087 & 2.1097 & 1.8331 \\
\hline Observations & 7934 & 7934 & 7934 & 7934 & 7934 & 7934 & 7934 & 7934 & 7934 & 7934 & 7934 & 7934 & 7934 & 7934 & 7934 & 7934 & 7934 \\
\hline
\end{tabular}

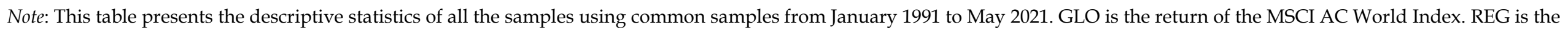
return of the MSCI AC Asia Pacific Index. The data from the Chinese domestic market was adjusted with the treatment of an outlier, as discussed in the data cleansing section. 
Table 2. Unconditional Correlation of Market Returns

\begin{tabular}{|c|c|c|c|c|c|c|c|c|c|c|c|c|c|c|c|c|c|}
\hline & \multicolumn{2}{|c|}{$\begin{array}{c}\text { Global and } \\
\text { Regional Market }\end{array}$} & \multicolumn{6}{|c|}{ Developed Markets } & \multicolumn{9}{|c|}{ Emerging Markets } \\
\hline & GLO & REG & USA & AUS & HKG & JPN & NZL & SGP & CHN & IDN & IND & KOR & MYS & PAK & PHL & THA & TWN \\
\hline$\overline{\mathrm{GLO}}$ & 1 & & & & & & & & & & & & & & & & \\
\hline REG & 0.4887 & 1 & & & & & & & & & & & & & & & \\
\hline USA & 0.1290 & 0.4374 & 1 & & & & & & & & & & & & & & \\
\hline AUS & 0.5222 & 0.5949 & 0.3762 & 1 & & & & & & & & & & & & & \\
\hline HKG & 0.3822 & 0.6184 & 0.3571 & 0.4939 & 1 & & & & & & & & & & & & \\
\hline JPN & 0.3158 & 0.8676 & 0.3851 & 0.4117 & 0.3823 & 1 & & & & & & & & & & & \\
\hline NZL & 0.3713 & 0.3929 & 0.3134 & 0.6259 & 0.3139 & 0.2820 & 1 & & & & & & & & & & \\
\hline SGP & 0.4298 & 0.5751 & 0.3086 & 0.5147 & 0.6178 & 0.3773 & 0.3904 & 1 & & & & & & & & & \\
\hline $\mathrm{CHN}$ & 0.0829 & 0.1675 & 0.0842 & 0.1408 & 0.1931 & 0.1020 & 0.0961 & 0.1436 & 1 & & & & & & & & \\
\hline IDN & 0.1755 & 0.3499 & 0.2298 & 0.2781 & 0.3511 & 0.2151 & 0.2098 & 0.4209 & 0.0801 & 1 & & & & & & & \\
\hline IND & 0.2805 & 0.3202 & 0.1771 & 0.3046 & 0.3156 & 0.1648 & 0.2074 & 0.3433 & 0.1224 & 0.2222 & 1 & & & & & & \\
\hline KOR & 0.3040 & 0.4926 & 0.2736 & 0.3999 & 0.4203 & 0.3260 & 0.2829 & 0.4207 & 0.1015 & 0.2723 & 0.2629 & 1 & & & & & \\
\hline MYS & 0.1979 & 0.3824 & 0.2518 & 0.2910 & 0.3919 & 0.2366 & 0.2237 & 0.4746 & 0.0760 & 0.3870 & 0.2012 & 0.2780 & 1 & & & & \\
\hline PAK & 0.0376 & 0.0802 & 0.0733 & 0.0710 & 0.0971 & 0.0539 & 0.0401 & 0.0934 & 0.0361 & 0.0948 & 0.0952 & 0.0508 & 0.0932 & 1 & & & \\
\hline PHL & 0.1860 & 0.3567 & 0.3397 & 0.3068 & 0.3538 & 0.2470 & 0.2485 & 0.3643 & 0.0891 & 0.3559 & 0.1992 & 0.2725 & 0.3015 & 0.0871 & 1 & & \\
\hline THA & 0.2668 & 0.3742 & 0.2056 & 0.3140 & 0.4028 & 0.2265 & 0.2508 & 0.4718 & 0.0950 & 0.3562 & 0.2497 & 0.3200 & 0.3887 & 0.0986 & 0.3309 & 1 & \\
\hline TWN & 0.2414 & 0.4427 & 0.2737 & 0.3418 & 0.3795 & 0.2882 & 0.2472 & 0.3879 & 0.1041 & 0.2514 & 0.2323 & 0.3560 & 0.2608 & 0.0836 & 0.2687 & 0.2622 & 1 \\
\hline
\end{tabular}


Table 3. Descriptive Statistics and Univariate Tests for Equality of The Global and Regional Market Integration

\begin{tabular}{|c|c|c|c|c|c|c|c|c|c|c|c|c|c|c|c|}
\hline & \multicolumn{6}{|c|}{ Developed Markets } & \multicolumn{9}{|c|}{ Emerging Markets } \\
\hline & USA & AUS & HKG & JPN & NZL & SGP & $\mathrm{CHN}$ & IDN & IND & KOR & MYS & PAK & PHL & THA & TWN \\
\hline \multicolumn{16}{|c|}{ Global Market Integration } \\
\hline Mean & 0.1777 & 0.5436 & 0.5858 & 0.6042 & 0.3302 & 0.4992 & 0.2014 & 0.3498 & 0.3852 & 0.5326 & 0.3179 & 0.0486 & 0.2672 & 0.4074 & 0.0449 \\
\hline Median & 0.1754 & 0.5117 & 0.5282 & 0.4810 & 0.3235 & 0.4677 & 0.1583 & 0.2724 & 0.4054 & 0.5749 & 0.2476 & 0.0364 & 0.2358 & 0.3681 & 0.0290 \\
\hline Maximum & 0.8679 & 1.4077 & 3.4300 & 3.0493 & 1.2009 & 3.6847 & 8.0429 & 6.1070 & 2.5748 & 3.9841 & 3.8003 & 2.7970 & 3.0193 & 3.7013 & 1.3088 \\
\hline Minimum & -0.5960 & -0.5366 & -0.7275 & -0.4632 & -1.1553 & -0.7480 & -7.6350 & -1.7200 & -1.9102 & -1.7899 & -0.6852 & -1.6177 & -1.4059 & -3.8868 & -0.2551 \\
\hline Std. Dev. & 0.1731 & 0.3247 & 0.4019 & 0.5089 & 0.2651 & 0.3608 & 0.7295 & 0.5394 & 0.4587 & 0.4441 & 0.4063 & 0.3275 & 0.4052 & 0.5118 & 0.0709 \\
\hline \multicolumn{16}{|c|}{ Regional Market Integration } \\
\hline Mean & 0.3571 & 0.5842 & 0.7626 & 1.0426 & 0.2936 & 0.5364 & 0.3331 & 0.5026 & 0.4198 & 0.7661 & 0.3978 & 0.0692 & 0.3957 & 0.4356 & 0.0614 \\
\hline Median & 0.3333 & 0.5758 & 0.7768 & 1.0508 & 0.2830 & 0.5402 & 0.3219 & 0.4594 & 0.4395 & 0.8444 & 0.3622 & 0.0569 & 0.3989 & 0.4155 & 0.0436 \\
\hline Maximum & 1.2693 & 1.7134 & 2.6298 & 1.9098 & 1.1332 & 1.5772 & 4.6548 & 2.9600 & 1.8632 & 2.4800 & 2.5288 & 2.3612 & 2.0258 & 2.6959 & 0.4620 \\
\hline Minimum & -0.2439 & -0.2553 & -0.3563 & 0.4195 & -0.6269 & -0.2295 & -2.3642 & -1.6443 & -1.3688 & -0.7887 & -0.3591 & -1.7659 & -1.1004 & -1.5177 & -0.1196 \\
\hline Std. Dev. & 0.2246 & 0.3062 & 0.3294 & 0.1965 & 0.1756 & 0.2580 & 0.4586 & 0.4300 & 0.3555 & 0.4676 & 0.2849 & 0.2555 & 0.3261 & 0.3447 & 0.0671 \\
\hline \multicolumn{16}{|c|}{ Test for Equality of Means Between Series: $t$-test value and $p$-value } \\
\hline Global vs Regional & -56.350 & -8.121 & -30.292 & -71.580 & 10.241 & -7.477 & -13.611 & -19.726 & -5.297 & -32.256 & -14.344 & -4.399 & -22.001 & -4.072 & -15.015 \\
\hline$p$-value & 0.0000 & 0.0000 & 0.0000 & 0.0000 & 0.0000 & 0.0000 & 0.0000 & 0.0000 & 0.0000 & 0.0000 & 0.0000 & 0.0000 & 0.0000 & 0.0000 & 0.0000 \\
\hline \multicolumn{16}{|c|}{ Test for Equality of Medians Between Series: Wilcoxon/Mann-Whitney value and $p$-value } \\
\hline Global vs Regional & 49.974 & 8.211 & 39.788 & 69.690 & 8.806 & 13.456 & 23.624 & 26.341 & 5.040 & 36.081 & 26.739 & 5.855 & 26.636 & 9.277 & 20.858 \\
\hline$p$-value & 0.0000 & 0.0000 & 0.0000 & 0.0000 & 0.0000 & 0.0000 & 0.0000 & 0.0000 & 0.0000 & 0.0000 & 0.0000 & 0.0000 & 0.0000 & 0.0000 & 0.0000 \\
\hline \multicolumn{16}{|c|}{ Test for Equality of Variances Between Series: F-Test value and $p$-value } \\
\hline Global vs Regional & 1.6838 & 1.1246 & 1.4892 & 6.7042 & 2.2789 & 1.9547 & 2.5306 & 1.5739 & 1.6648 & 1.1084 & 2.0331 & 1.6439 & 1.5433 & 2.2049 & 1.1190 \\
\hline$p$-value & 0.0000 & 0.0000 & 0.0000 & 0.0000 & 0.0000 & 0.0000 & 0.0000 & 0.0000 & 0.0000 & 0.0000 & 0.0000 & 0.0000 & 0.0000 & 0.0000 & 0.0000 \\
\hline
\end{tabular}

Note: This table reports the global and regional integration statistics, which are estimated using the BEKK-GARCH. 
Figures 1,2, and 3 show the integration levels of the domestic markets to the global and regional markets vary over time; at certain times, there seems to be greater volatility than for most of the period. They show that regional market integration tends to have an upward trend compared to global market integration. In the long run, there is a phenomenon of increased regional market integration in both the developed and emerging markets, which is inherent to the global market integration (see, Figure 3 ). This result supports Chelley-Steeley (2004), who examined market integration in the AsiaPacific region and found that the market integration process between Asia-Pacific countries was faster than for their integration with the global market. This result also confirms previous related studies about strengthening regional integration over time (Caporale et al., 2021; Chevallier et al., 2018; Sehgal et al., 2018). In general, the domestic markets have contemporaneous co-movement to the global and regional market, which varies over time due to the exposure of global and regional factors to the domestic markets changes.

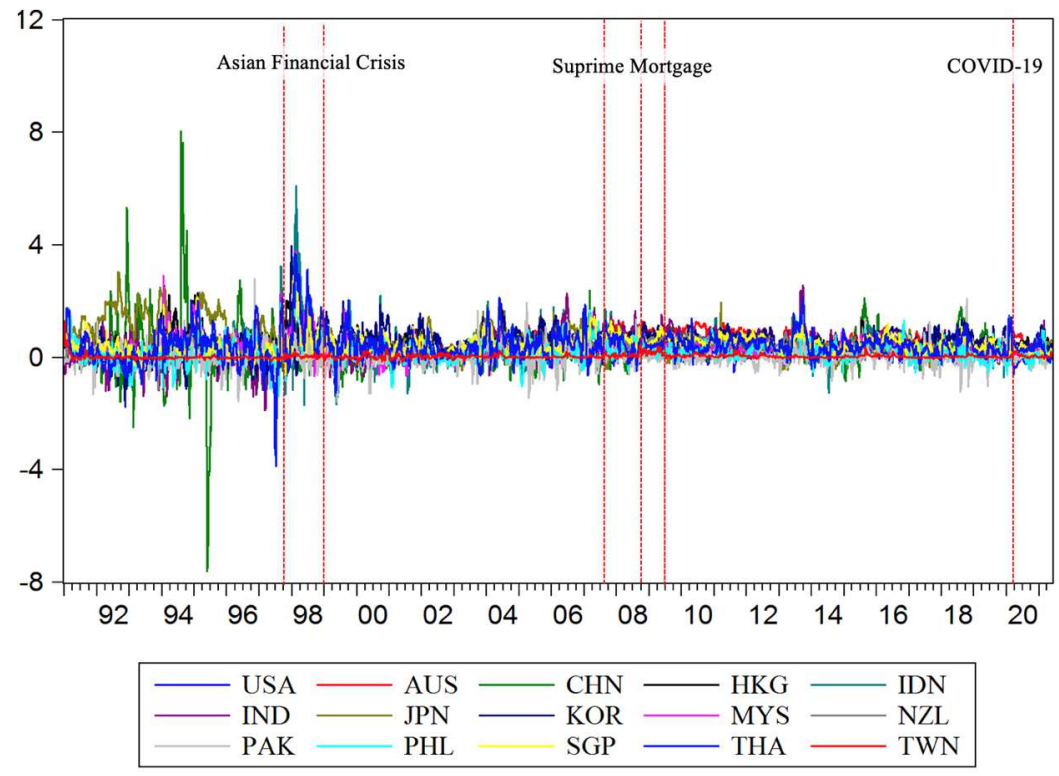

Figure 1. Time-Varying Integration of Global Market

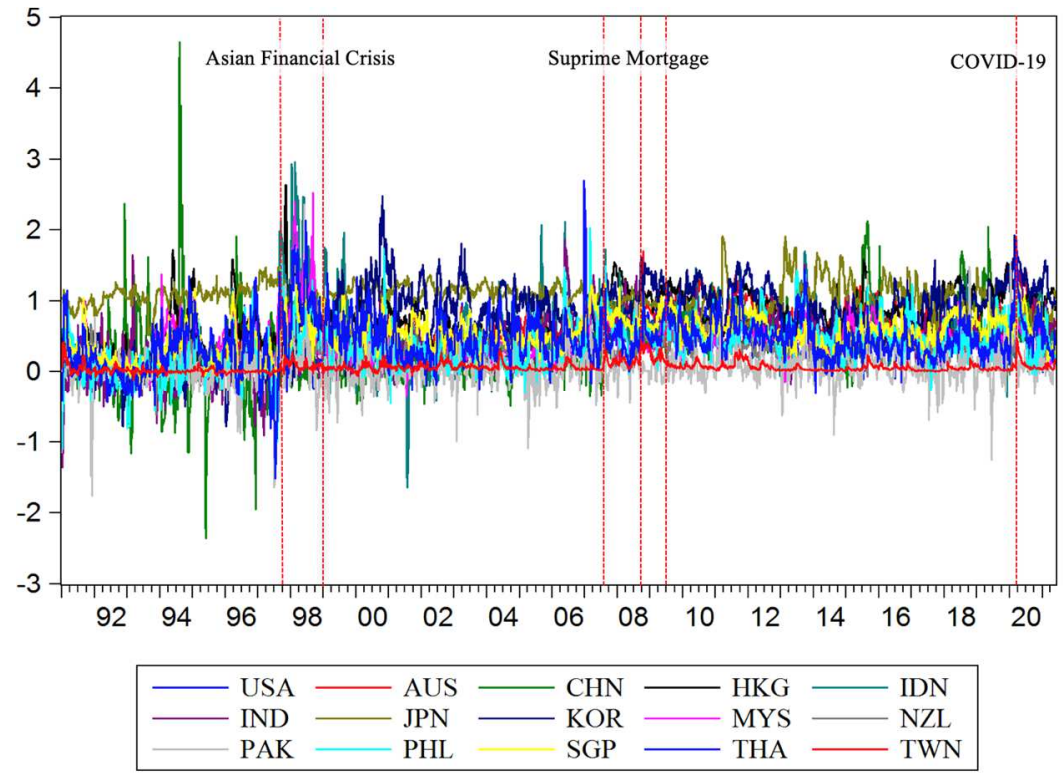

Figure 2. Time-Varying Integration of Regional Market 


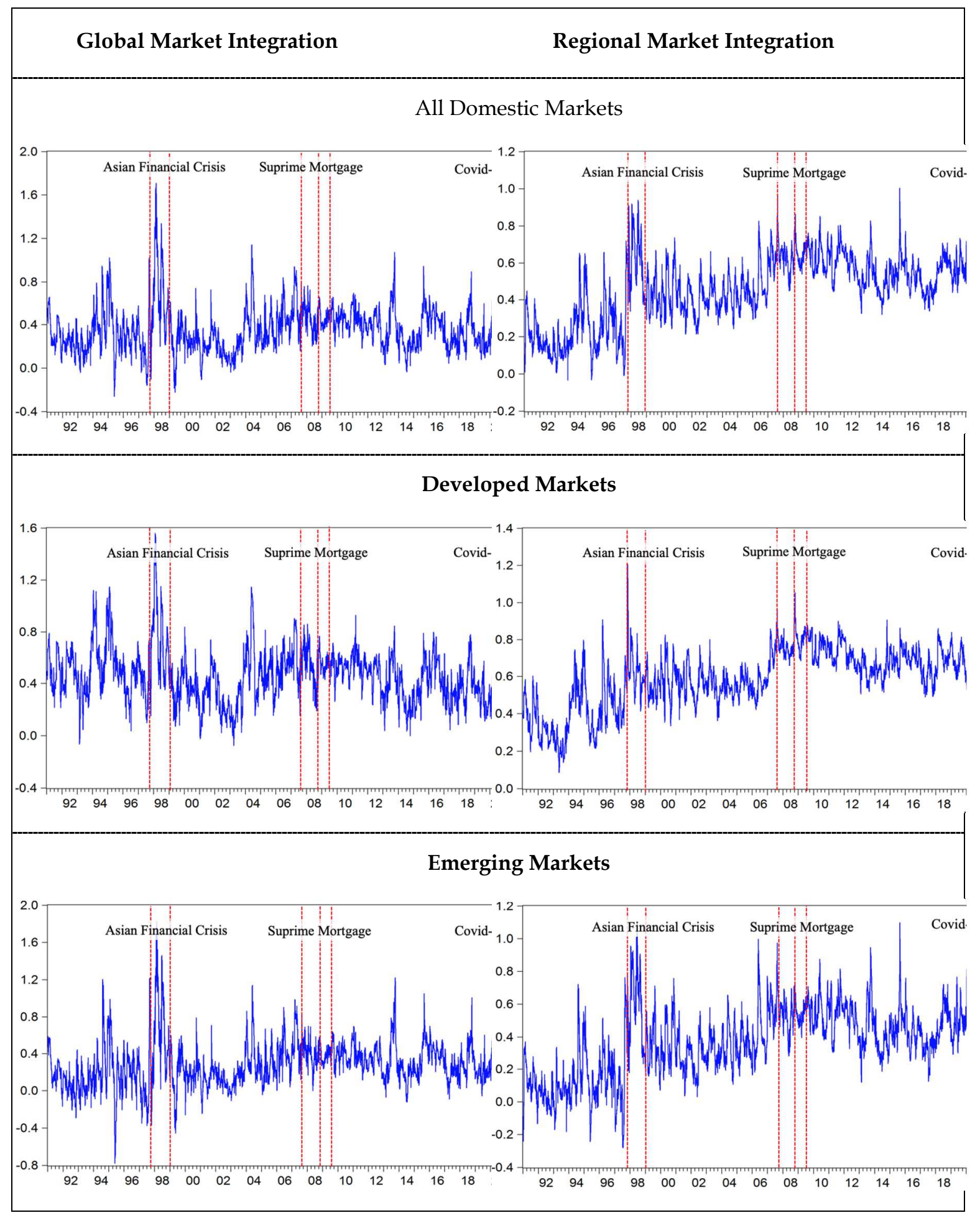

Figure 3. Averages of Global and Regional Market Integration

\section{Market Integration and Financial Crises}

Figures 1, 2, and 3 show that the Asian financial crisis affected the volatility of the market integration to a greater extent than the subprime mortgage crisis did in both the global and regional market integration. The Asian financial crisis is an economic crisis that has a broad impact on macroeconomic stability, which began with the depreciation of currencies in the Asian region and spread globally. Meanwhile, the subprime mortgage 
crisis is influenced more by risk perceptions; companies that previously had good ratings (i.e., Lehman Brothers, and American International Group/AIG) entered bankruptcy, which caused an increase in investors' perceptions about market risk, especially for the developed markets that were adjusted to the price of assets.

These figures show a sharp increase in market integration at the beginning of the crises period, partially supporting the previous research (see Berger \& Pukthuanthong, 2012; Pukthuanthong \& Roll, 2009). The probability of a global financial crisis is higher during periods when most domestic markets are exposed to high global factors because a shock to the world markets can simultaneously be spread to many other markets. This perspective relates to the disadvantages of increased market integration and the globalization hypothesis that the worst crisis occurs in countries that are highly integrated through global trade and financial linkages. These figures also show the gradual decrease in market integration during a crisis period, which supports the previous research (see Bekaert et al., 2011, 2014) that found integration decreased during crisis periods and showed a gradual decline in market integration previous level. They found that the most integrated countries, especially if they were also developed countries, did not suffer during a crisis. Meanwhile, countries with weak economic fundamentals, poor sovereign ratings, high fiscal and current account deficits were more affected by crises. This perspective relates to the advantages of increased market integration, which can mitigate shocks by absorbing the impact of crises, thereby minimizing the chance of crises spreading to other markets.

The recent crisis triggered by Covid-19 is different. During the crisis, these figures show the dynamics of market integration both globally and regionally. Figure 3 shows a sharp decline in market integration, especially in early of the crisis period. Since the crisis started in March 2020, the Covid-19 had a significant impact on the real economy, and the domestic markets have responded with more segmented. This crisis is different from previous financial crises; in fact, the Covid-19 has led to economic damage globally (Ashraf, 2020; Goodell, 2020).

To get a better perspective of the dynamics of market integration, we also study this question more formally using equations (9), which is derived from the CAPM, to understand the different effects of market integration on excess returns during a crisis and non-crisis periods. The estimation of the model uses the ordinary least squares (OLS) with a fixed effect for two different global financial crises periods and the Covid-19 period.

Table 4. Global Market Integration and Financial Crises

\begin{tabular}{lcccccccc}
\hline & \multicolumn{6}{c}{ Dependent Variable: Excess Return } \\
\cline { 2 - 8 } & \multirow{2}{*}{ Model I } & \multicolumn{5}{c}{ Model II } \\
\cline { 3 - 8 } & & \multicolumn{1}{c}{$\mathbf{1}^{\text {st }}$ Crisis Period } & $\begin{array}{c}\mathbf{2}^{\text {nd }} \text { Crisis } \\
\text { Period }\end{array}$ & Covid-19 Period \\
\hline Intercept & 0.000068 & 0.000229 & $* * *$ & 0.000171 & $* * *$ & 0.000034 \\
Global Beta (Market & 0.000519 & $* * *$ & 0.000404 & $* * *$ & 0.000434 & $* * *$ & 0.000564 & $* * *$ \\
Integration) & & -0.001900 & $* * *$ & -0.001736 & $* * *$ & 0.000844 & $* * *$ \\
Crisis & & 0.001338 & $* * *$ & 0.001132 & $* * *$ & -0.002213 & $* * *$ \\
Global Beta * Crisis & 0.000240 & 0.001010 & & 0.000692 & & 0.000337 & \\
R-squared & 0.000103 & 0.000868 & & 0.000549 & & 0.000194 \\
Adjusted R-squared & & & & & & & &
\end{tabular}




\begin{tabular}{lcccc}
\hline & \multicolumn{3}{c}{ Dependent Variable: Excess Return } \\
\cline { 2 - 5 } & Model I & \multicolumn{3}{c}{ Model II } \\
\cline { 2 - 5 } & & $\mathbf{1}^{\text {st }}$ Crisis Period & $\begin{array}{c}\mathbf{2}^{\text {nd }} \text { Crisis } \\
\text { Period }\end{array}$ & Covid-19 Period \\
\hline S.E. of regression & 0.015837 & 0.015653 & 0.015656 & 0.015659 \\
F-statistic & $1.886196^{* *}$ & $7.078292 * * *$ & $4.843593 * * *$ & $2.356408^{* * *}$ \\
Total observations (balanced) & 119,010 & 119,010 & 119,010 & 119,010 \\
\hline
\end{tabular}

Note: This table presents the relationship between the level of the global market integration (estimated using BEKK-GARCH), crises, and excess return. Model I: $R_{i t}-R_{f t}=a+b \hat{\beta}_{i t}+\varepsilon_{i t}$ as equation (9), and model II: $R_{i t}-R_{f t}=a_{1}+b_{1} \hat{\beta}_{i t}+b_{2}$ Crisis $_{t}+b_{3}$ Crisis $_{t} * \hat{\beta}_{i t}+\varepsilon_{i t}$ As equation (10), the $1^{\text {st }}$ crisis period is the Asian financial crisis from 10/1997 to $12 / 1998$, and the subprime mortgage crisis is from $8 / 2007$, which was the initial fall in the stock markets due to the liquidity crisis, to 6/2009. The $2^{\text {nd }}$ crisis period is the Asian financial crisis from 10/1997 to 12/1998, and the subprime mortgage crisis is from 9/2008, which was when Lehman Brothers collapsed, to 6/2009. The Covid-19 period starts from the crash on March 2020 triggered by Covid19. All the models are estimated using pooled OLS with a fixed effect. ${ }^{*}, * *$, and ${ }^{* * *}$ denote statistical significance at the $10 \%, 5 \%$, and $1 \%$ levels, respectively.

Table 4 shows that the global market integration significantly affects the excess returns using all the models and periods with a significant F-statistic value. The global market integration is positively related to the excess returns with the global beta estimate of 0.000519 . The relationship becomes stronger during the financial crises for both the first and second crises periods, with the marginal effect of the global beta estimate to be 0.001742 and 0.001566 . Meanwhile, the financial crises are negatively related to the excess returns for the first and second periods, with the marginal effect of the crisis estimates being -0.000562 and -0.000604 , respectively. The global market integration is positively related to the market return, but the financial crisis is negatively related.

During the Covid-19 period, the financial crises are negatively related to the excess returns with the marginal effect of the crisis estimates of -0.001369 . It shows that the crisis triggered by Covid-19 has a different effect on the market return, which is more negative or exacerbates the market return. This finding is consistent with previous studies that the pandemic of Covid-19 has generated negative shocks on the equity markets across the world (Phan \& Narayan, 2020). It also supports most previous studies showing the stock markets in the world reacted to the Covid-19 pandemic with unprecedented volatility and strong negative return (Ashraf, 2020; Harjoto et al., 2021; Mazur et al., 2021).

This finding indirectly supports the previous research that the relationship between a crisis and market integration was negatively related (Lehkonen, 2015). The segmentation increased during crisis periods, which showed a gradual decline in market integration during crises periods (Bekaert et al., 2011, 2014). During the crisis periods, the global market integration is positively related to the excess returns. In general, if the level of integration is decreased, then the excess returns also decreased. This is consistent with the negative relationship between the crises period and the excess returns, where there is a decrease in the excess returns during a crisis period. The role of the global market integration in the crisis periods is very significant; it has a joint impact on the interaction between the global beta and the crisis, making them positive and significant, except during the Covid-19 period in which the effect of the crisis is more dominant to exacerbate the return. 
Table 5. Regional Market Integration and Financial Crises

\begin{tabular}{lcccc}
\hline & \multicolumn{3}{c}{ Dependent Variable: Excess Return } \\
\cline { 2 - 5 } & \multirow{2}{*}{ Model I } & \multicolumn{3}{c}{ Model II } \\
\cline { 3 - 5 } & & $\mathbf{1}^{\text {st }}$ Crisis Period & $\begin{array}{c}\mathbf{2}^{\text {nd }} \text { Crisis } \\
\text { Period }\end{array}$ & Covid-19 Period \\
\hline Intercept & $0.000167^{* *}$ & $0.000256^{* * *}$ & $0.000228^{* * *}$ & $0.000141^{*}$ \\
Regional Beta (Market & 0.000181 & 0.000240 & 0.000194 & 0.000211 \\
Integration) & & $-0.001768^{* * *}$ & $-0.001547^{* * *}$ & $0.000736^{* *}$ \\
Crisis & & $0.001048 * * *$ & $0.000914 * *$ & $-0.000905^{*}$ \\
Regional Beta * Crisis & 0.000054 & 0.000604 & 0.000350 & 0.000091 \\
R-squared & - & 0.000461 & 0.000208 & -0.000052 \\
Adjusted R-squared & 0.000072 & 0.015657 & 0.015659 & 0.015661 \\
S.E. of regression & 0.015661 & $4.229213 * * *$ & $2.453687 * * *$ & 0.637677 \\
F-statistic & 0.426801 & 119,010 & 119,010 & 119,010 \\
Total observations (balanced) & 119,010 & &
\end{tabular}

Note: This table presents the relationship between the level of the regional market integration (estimated using BEKK-GARCH), crises, and excess return. Model I: $R_{i t}-R_{f t}=a+b \hat{\beta}_{i t}+\varepsilon_{i t}$ as equation (9), and model II: $R_{i t}-R_{f t}=a_{1}+b_{1} \hat{\beta}_{i t}+b_{2}$ Crisis $_{t}+b_{3}$ Crisis $_{t} * \hat{\beta}_{i t}+\varepsilon_{i t}$ As equation (10), the $1^{\text {st }}$ crisis period is the Asian financial crisis from $10 / 1997$ to $12 / 1998$, and the subprime mortgage crisis is from $8 / 2007$, which was the initial fall in the stock markets due to the liquidity crisis, to $6 / 2009$. The $2^{\text {nd }}$ crisis period is the Asian financial crisis from 10/1997 to 12/1998, and the subprime mortgage crisis is from $9 / 2008$, which was when Lehman Brothers collapsed, to 6/2009. The Covid-19 period starts from the crash on March 2020 triggered by Covid19. All the models are estimated using pooled OLS with a fixed effect. *,**, and *** denote statistical significance at the $10 \%, 5 \%$, and $1 \%$ levels, respectively.

Table 5 explores the regional market integration, the global financial crises, and the crisis triggered by Covid-19. It shows that the regional market integration has a significant effect only during the first and second crisis periods with a significant Fstatistic value. The model of regional market integration during the Covid-19 period has no significant effect on the excess return. Still, it is more affected by the global market and dominated by the impact of the crisis. The financial crisis is negatively related to excess returns in both the first and second periods, with the marginal effect of the crisis estimate of -0.000720 and -0.000633 . This finding indicates the emergence of a regional role in the domestic markets during a crisis period, although there is a time-varying of regional market integration. The role of the regional market integration in the crisis periods changes to be significant, with a joint impact on the interaction between the regional beta and crisis being positive and significant, with the marginal effects in both the first and second periods of 0.001048 and 0.000914 , respectively. It shows that the global market influences the domestic markets in general and the global and regional markets during the financial crises. During financial crisis periods, there is a market segmentation due to increasing the regional factor.

In beta as a parameter of market risk, they show that global market risk is positive and significant to affect the return. Still, the return will be lower during the financial crises. The regional market risk is significant only during the financial crisis period; therefore, in the case of a partially integrated market, the asset return is affected not only by global and local factors but also by regional factors. During the financial crisis, the joint impact on the interaction between the market risk and crisis is positive and significant, meaning the high-risk assets will get higher returns during crisis periods. Meanwhile, during the Covid-19 period, the joint impact is negative and significant because the crisis 
is more dominating the impact to the return. It shows that the crisis triggered by Covid-19 is different and worse than the previous financial crises.

\section{CONCLUSION, LIMITATIONS, AND SUGGESTIONS}

\section{Conclusion}

International financial markets have been developing rapidly due to liberalization and globalization over the last four decades, increasing market integration. The increase in the various market integration provides both advantages and disadvantages and direct and indirect implications. The most important implication about these advantages that must be carefully considered is the need to mitigate the various risks associated with the time-varying market integration globally and regionally.

We find that the domestic market is influenced by local and global factors and regional factors, especially during a financial crisis period. We examine the relationship between excess returns and market integration during the financial crisis period and find the emergence of the region's role during a crisis period. This finding is interesting. Under normal conditions, only the global factor has a significant effect on domestic markets, but during the crisis period, it indicates the emergence of the region's role in the domestic markets. We also examine this relationship during the crisis triggered by Covid-19 and find the crisis is a dominant factor to exacerbate the market return globally, and there is no role of the regional market during the Covid-19 period. The crisis also affects the stock markets, which was worse than the previous financial crises.

The result shows that the market integrations are time-varying both globally and regionally. However, the regional market integration indicates an upward trend in the developed and emerging markets over the long run, which is inherent to global market integration. This finding also confirms the effect of a financial crisis on the level of integration with previous studies (see, Lehkonen, 2015); since during a crisis period, there is a decline in market integration which also causes a decline in market returns. Meanwhile, the result for global market integration support the findings of previous studies; the integration level of a domestic market with the global market is time-varying or changes over time (M. E. H. Arouri et al., 2012; Bekaert et al., 2011; Bekaert \& Harvey, 1995; Carrieri et al., 2006; Pukthuanthong \& Roll, 2009).

\section{Limitations and suggestions}

We measure the market integration using price-based indicators, which directly measure the integration; therefore, they provide an easy interpretation compared to quantity-based indicators, which rely solely on data flow or institutional indicators based on regulatory measures (Volosovych, 2011). The model in this study is only derived from the capital asset pricing model (CAPM) developed by Sharpe (1964), Lintner (1965), and Mossin (1966), which is a robust asset pricing model that we extended to the international context using the law of one price theory. Further research may use another based indicator to measure the market integration level, such as quantity-based or institutional indicators. The models also may be extended using control variables such as market size or macroeconomics.

For the investors in stock markets, time-varying market integration should be an essential concern for portfolio management, which directly impacts the benefit of international diversification. They are suggested to use dynamic strategies for their portfolio to adjust the time-varying market integration, especially during crisis and non- 
crisis periods. Investors must be aware of the stock market cycles in which the role of the regional market emerges during financial crisis periods.

\section{Acknowledgment}

The author would like to thank dissertation advisers Marwan Asri, Kusdhianto Setiawan, and Bowo Setiyono. We also thank an anonymous referee for several constructive comments and suggestions on an earlier version. This article is a part of the author's dissertation; any remaining errors and omissions are my responsibility alone. Financial support from the Ministry of Education and Culture for the Beasiswa Unggulan Program is gratefully acknowledged.

\section{REFERENCES}

Akbari, A., Ng, L., \& Solnik, B. (2020). Emerging Markets Are Catching Up: Economic or Financial Integration? Journal of Financial and Quantitative Analysis, 55(7), 2270-2303. https:// doi.org/10.1017/S0022109019000681

Al Nasser, O. M., \& Hajilee, M. (2016). Integration of emerging stock markets with global stock markets. Research in International Business and Finance, 36, 1-12. https:// doi.org/10.1016/j.ribaf.2015.09.025

Arouri, M. E. H., Nguyen, D. K., \& Pukthuanthong, K. (2012). An international CAPM for partially integrated markets: Theory and empirical evidence. Journal of Banking $\mathcal{E}$ Finance, 36(9), 2473-2493. https:/ / doi.org/10.1016/j.jbankfin.2012.05.004

Arouri, M., Teulon, F., \& Rault, C. (2013). Equity risk premium and regional integration. International Review of Financial Analysis, 28, 79-85. https:// doi.org/10.1016/j.irfa.2013.02.009

Ashraf, B. N. (2020). Stock markets' reaction to COVID-19: Cases or fatalities? Research in International Business and 101249. https:// doi.org/10.1016/j.ribaf.2020.101249

Bekaert, G. (1995). Market Integration and Investment Barriers in Emerging Equity Markets. The World Bank Economic Review, 9(1), 75-107. https:// doi.org/10.1093/wber/9.1.75

Bekaert, G., Ehrmann, M., Fratzscher, M., \& Mehl, A. (2014). The Global Crisis and Equity Market Contagion: The Global Crisis and Equity Market Contagion. The Journal of Finance, 69(6), 2597-2649. https:// doi.org/10.1111/jofi.12203

Bekaert, G., \& Harvey, C. R. (1995). Time-Varying World Market Integration. The Journal of Finance, 50(2), 403. https:/ / doi.org/10.2307/2329414

Bekaert, G., \& Harvey, C. R. (2003). Emerging markets finance. Journal of Empirical Finance, 53.

Bekaert, G., Harvey, C. R., \& Lundblad, C. T. (2003). Equity Market Liberalization in Emerging Markets. The Journal of Financial Research, 26(3), 275-299. https:// doi.org/10.1111/1475-6803.00059

Bekaert, G., Harvey, C. R., Lundblad, C. T., \& Siegel, S. (2011). What Segments Equity Markets? The Review of Financial Studies, 24(12), 3841-3890. https:// doi.org/10.1093/rfs/hhr082 
Berger, D., \& Pukthuanthong, K. (2012). Market fragility and international market crashes. Journal of Financial Economics, 105(3), 565-580. https:// doi.org/10.1016/j.jfineco.2012.03.009

Billio, M., Donadelli, M., Paradiso, A., \& Riedel, M. (2017). Which market integration measure? Journal of Banking $\mathcal{E}$ Finance, 76, 150-174. https:// doi.org/10.1016/j.jbankfin.2016.12.002

Boamah, N. A. (2017). The global financial market integration of selected emerging markets. International Journal of Emerging Markets, 12(4), 683-707. https:// doi.org/10.1108/IJoEM-11-2015-0241

Caporale, G. M., Gil-Alana, L. A., \& You, K. (2021). Global and Regional Financial Integration in Emerging Asia: Evidence from Stock Markets. Journal of Economic Integration, 36(2), 185-202. https:/ / doi.org/10.11130/jei.2021.36.2.185

Carrieri, F., Errunza, V., \& Hogan, K. (2007). Characterizing World Market Integration through Time. The Journal of Financial and Quantitative Analysis, 42, 915-940. https:// doi.org/10/1017/S0022109000003446

Carrieri, F., Errunza, V., \& Majerbi, B. (2006). Local risk factors in emerging markets: Are they separately priced? Journal of Empirical Finance, 13(4-5), 444-461. https:// doi.org/10.1016/j.jempfin.2005.12.002

Chelley-Steeley, P. (2004). Equity market integration in the Asia-Pacific region: A smooth transition analysis. International Review of Financial Analysis, 12. https:/ / doi.org/10.1016/j.irfa.2004.02.016

Chelley-Steeley, P. L., Steeley, J. M., \& Pentecost, E. J. (1998). Exchange controls and European stock market integration. Applied Economics, 30(2), 263-267. https:/ / doi.org/10.1080/000368498326056

Chevallier, J., Nguyen, D. K., Siverskog, J., \& Uddin, G. S. (2018). Market integration and financial linkages among stock markets in Pacific Basin countries. Journal of Empirical Finance, 46, 77-92. https://doi.org/10.1016/j.jempfin.2017.12.006

Choudhry, T., Lu, L., \& Peng, K. (2010). Time-varying beta and the Asian financial Crisis: Evidence from the Asian industrial sectors. Japan and the World Economy, 22(4), 228234. https:// doi.org/10.1016/j.japwor.2010.06.003

Engle, R. (2002). Dynamic Conditional Correlation: A Simple Class of Multivariate Generalized Autoregressive Conditional Heteroskedasticity Models. Journal of Business $\mathcal{E}$ Economic Statistics, 339-350. https:// doi.org/10.1198/073500102288618487

Engle, R. F., Ghysels, E., \& Sohn, B. (2013). Stock Market Volatility and Macroeconomic Fundamentals. Review of Economics and Statistics, 95(3), 776-797. https://doi.org/10.1162/REST_a_00300

Fratzscher, M. (2002). Financial market integration in Europe: On the effects of EMU on stock markets. International Journal of Finance $\mathcal{E}$ Economics, 7(3), 165-193. https:// doi.org/10.1002/ijfe.187 
Goodell, J. W. (2020). COVID-19 and finance: Agendas for future research. Finance Research Letters, 35, 101512. https:// doi.org/10.1016/j.frl.2020.101512

Harjoto, M. A., Rossi, F., \& Paglia, J. K. (2021). COVID-19: Stock market reactions to the shock and the stimulus. Applied Economics Letters, 28(10), 795-801. https:// doi.org/10.1080/13504851.2020.1781767

Jeon, J., Oh, Y., \& Yang, D. Y. (2006). Financial Market Integration in East Asia: Regional or Global? Asian Economic Papers, 5(1), 73-89. https:// doi.org/10.1162/asep.2006.5.1.73

Karolyi, G. A., \& Stulz, R. M. (2002). Are Financial Assets Priced Locally or Globally? (Working Paper No. 8994; NBER WORKING PAPER SERIES). NATIONAL BUREAU OF ECONOMIC RESEARCH. https:// www.nber.org/papers/w8994

Kearney, C., \& Lucey, B. M. (2004). International equity market integration: Theory, evidence and implications. International Review of Financial Analysis, 13(5), 571-583. https://doi.org/10.1016/j.irfa.2004.02.013

Kose, M. A., Prasad, E. S., \& Terrones, M. E. (2009). Does financial globalization promote risk sharing? Journal of Development Economics, 89(2), 258-270. https:// doi.org/10.1016/j.jdeveco.2008.09.001

Lee, H., \& Kim, H. (2020). Time varying integration of European stock markets and monetary drivers. Journal of Empirical Finance, 58, 369-385. https:// doi.org/10.1016/j.jempfin.2020.07.004

Lehkonen, H. (2015). Stock Market Integration and the Global Financial Crisis. Review of Finance, 19(5), 2039-2094. https:/ / doi.org/10.1093/rof/rfu039

Lintner, J. (1965). The Valuation of Risk Assets and the Selection of Risky Investments in Stock Portfolios and Capital Budgets. The Review of Economics and Statistics, 47(1), 13. https:// doi.org/10.2307/1924119

Markowitz, H. (1952). Portfolio Selection. The Journal of Finance, 7(1), 77. https:// doi.org/10.2307/2975974

Mazur, M., Dang, M., \& Vega, M. (2021). COVID-19 and the march 2020 stock market crash. Evidence from S\&P1500. Finance Research Letters, 38, 101690. https:// doi.org/10.1016/j.frl.2020.101690

Mossin, J. (1966). Equilibrium in a Capital Asset Market. Econometrica, 34(4), 768. https:// doi.org/10.2307/1910098

Muharam, H., Robiyanto, R., Pangestuti, I., \& Mawardi, W. (2020). Measuring Asian Stock Market Integration by Using Orthogonal Generalized Autoregressive Conditional Heteroscedasticity. Montenegrin Journal of Economics, 16(1), 121-137. https:// doi.org/10.14254/1800-5845/2020.16-1.8

Narayan, S., Sriananthakumar, S., \& Islam, S. Z. (2014). Stock market integration of emerging Asian economies: Patterns and causes. Economic Modelling, 39, 19-31. https:// doi.org/10.1016/j.econmod.2014.02.012 
Paramati, S. R., Roca, E., \& Gupta, R. (2016). Economic integration and stock market dynamic linkages: Evidence in the context of Australia and Asia. Applied Economics, 48(44), 4210-4226. https:/ / doi.org/10.1080/00036846.2016.1153794

Phan, D. H. B., \& Narayan, P. K. (2020). Country Responses and the Reaction of the Stock Market to COVID-19-A Preliminary Exposition. Emerging Markets Finance and Trade, 56(10), 2138-2150. https:/ / doi.org/10.1080/1540496X.2020.1784719

Pukthuanthong, K., \& Roll, R. (2009). Global market integration: An alternative measure and its application ${ }^{2}$. Journal of Financial Economics, 94(2), 214-232. https:/ / doi.org/10.1016/j.jfineco.2008.12.004

Robiyanto, R. (2018a). Indonesian Stock Market's Dynamic Integration with Asian Stock Markets and World Stock Markets. Jurnal Pengurusan, 52, 181-192. https:// doi.org/10.17576/pengurusan-2018-52-15

Robiyanto, R. (2018b). The Dynamic Correlation between ASEAN-5 Stock Markets and World Oil Prices. Jurnal Keuangan Dan Perbankan, 22(2). https:// doi.org/10.26905/jkdp.v22i2.1688

Sehgal, S., Pandey, P., \& Deisting, F. (2018). Stock Market Integration Dynamics and its Determinants in the East Asian Economic Community Region. Journal of Quantitative Economics, 16(2), 389-425. https:/ / doi.org/10.1007/s40953-017-0090-7

Setiawan, K. (2012). International Asset Pricing Under Partially Integrated Market [Dissertation]. Hiroshima University of Economics.

Setiawan, K. (2014). Stock Market Integration: Are Risk Premiums of International Assets Equal? Gadjah Mada International Journal of Business, 16(1), 39. https:/ / doi.org/10.22146/gamaijb.5466

Sharpe, W. F. (1964). Capital Asset Prices: A Theory of Market Equilibrium under Conditions of Risk. The Journal of Finance, 19(3), 425-442. https:// doi.org/10.2307/2977928

WHO. (2020). Coronavirus Disease (COVID-2019) Situation Reports (No. 51). World Health Organization. https://www.who.int/emergencies/diseases/novel-coronavirus2019/situation-reports

WHO. (2021). Weekly Operational Update on COVID-19 May 312021 (p. 15). World Health Organization. https://www.who.int/publications/m/item/weekly-operationalupdate-on-covid-19-31-may-2021

Yu, I.-W., Fung, K.-P., \& Tam, C.-S. (2010). Assessing financial market integration in Asia - Equity markets. Journal of Banking \& Finance, 34(12), 2874-2885. https://doi.org/10.1016/j.jbankfin.2010.02.010 


\section{Endnotes}

1. The cooperation between the WTO, World Bank, and IMF are stated in several agreements, ministerial declarations, and decisions. See the WTO Annual reports on coherence to the WTO General Council by the Director-General, World Bank President, and IMF Managing Director; and general documents on Coherence in Global Economic Policy-Making: WTO Cooperation with the IMF and the World Bank.

2. The market capitalization of the Asia-Pacific region, including the USA, is $74 \%$ of the world in 2017 based on World Bank data. Source: data.worldbank.org, September 7, 2019. 


\section{Appendices}

Appendix A. Descriptive Statistics and Univariate Tests for Equality of the Global and Regional Market Integration

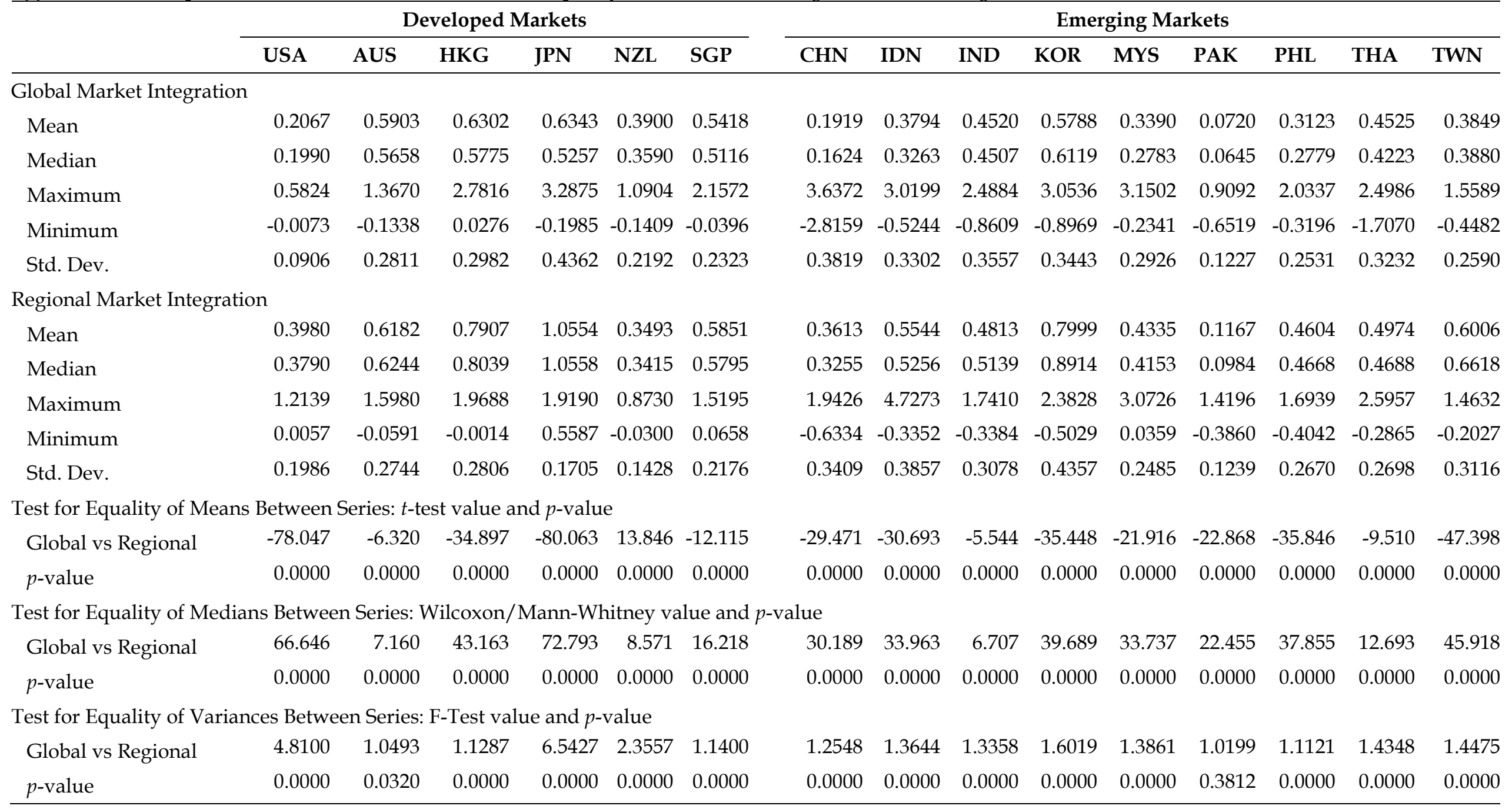

Note: This table reports descriptive statistics of the global and regional intergration which estimated using the DCC-GARCH. 
Appendix B. Global Market Integration and Financial Crisis

\begin{tabular}{|c|c|c|c|c|}
\hline & \multicolumn{4}{|c|}{ Dependent Variable: Excess Return } \\
\hline & \multirow[b]{2}{*}{ Model I } & \multicolumn{3}{|c|}{ Model II } \\
\hline & & $\begin{array}{c}\text { 1 }^{\text {st }} \text { Crisis } \\
\text { Period }\end{array}$ & $\begin{array}{c}2^{\text {nd }} \text { Crisis } \\
\text { Period }\end{array}$ & $\begin{array}{c}\text { Covid-19 } \\
\text { Period } \\
\end{array}$ \\
\hline Intercept & $-0.000203 * * *$ & -0.000007 & -0.000075 & -0.000213 *** \\
\hline Global Beta (Market Integration) & $0.001104^{* * *}$ & $0.000937 * * *$ & $0.000977^{* * *}$ & 0.001088 *** \\
\hline Crisis & & $-0.002457 * * *$ & $-0.002127 * * *$ & -0.000240 \\
\hline Global Beta * Crisis & & $0.002251 * * *$ & $0.001821 * * *$ & 0.001422 \\
\hline R-squared & 0.000472 & 0.001377 & 0.000977 & 0.000512 \\
\hline Adjusted R-squared & 0.000346 & 0.001235 & 0.000834 & 0.000369 \\
\hline S.E. of regression & 0.015659 & 0.015652 & 0.015655 & 0.015659 \\
\hline F-statistic & $3.744840 * * *$ & $9.650948^{* * *}$ & $6.844342 * * *$ & $3.584313 * * *$ \\
\hline Total observations (balanced) & 119,010 & 119,010 & 119,010 & 119,010 \\
\hline
\end{tabular}

Note: This table presents the relationship between the level of the global market integration (estimated using DCC-GARCH), crises, and excess return. Model I: $R_{i t}-R_{f t}=a+b \hat{\beta}_{i t}+\varepsilon_{i t}$ as equation (9), and model II: $R_{i t}-R_{f t}=a_{1}+b_{1} \hat{\beta}_{i t}+b_{2}$ Crisis $_{t}+b_{3}$ Crisis $_{t} * \hat{\beta}_{i t}+\varepsilon_{i t}$ As equation (10), the $1^{\text {st }}$ crisis period is the Asian financial crisis from $10 / 1997$ to $12 / 1998$, and the subprime mortgage crisis is from $8 / 2007$, which was the initial fall in the stock markets due to the liquidity crisis, to 6/2009. The $2^{\text {nd }}$ crisis period is the Asian financial crisis from 10/1997 to 12/1998, and the subprime mortgage crisis is from 9/2008, which was when Lehman Brothers collapsed, to 6/2009. The Covid-19 period starts from the crash on March 2020 triggered by Covid19. All the models are estimated using pooled OLS with a fixed effect. ${ }^{*}, * *$, and *** denote statistical significance at the $10 \%, 5 \%$, and $1 \%$ levels, respectively.

Appendix C. Regional Market Integration and Financial Crisis

\begin{tabular}{lcccc}
\hline & \multicolumn{4}{c}{ Dependent Variable: Excess Return } \\
\cline { 2 - 5 } & \multirow{2}{*}{ Model I } & \multicolumn{3}{c}{ Model II } \\
\cline { 2 - 5 } & & $\begin{array}{c}\mathbf{1}^{\text {st }} \text { Crisis } \\
\text { Period }\end{array}$ & $2^{\text {nd }}$ Crisis Period & $\begin{array}{c}\text { Covid-19 } \\
\text { Period }\end{array}$ \\
\hline Intercept & 0.000012 & 0.000157 & 0.000147 & 0.000023 \\
Regional Beta (Market & $0.000442 * * *$ & $0.000389 * *$ & $0.000316^{*}$ & $0.000405^{* *}$ \\
Integration) & & $-0.002208 * * *$ & $-0.002118^{* * *}$ & -0.000164 \\
Crisis & & $0.001647 * * *$ & $0.001774 * * *$ & 0.000413 \\
Regional Beta * Crisis & 0.000101 & 0.000745 & 0.000500 & 0.000109 \\
R-squared & -0.000025 & 0.000602 & 0.000357 & -0.000034 \\
Adjusted R-squared & 0.015662 & 0.015657 & 0.015659 & 0.015662 \\
S.E. of regression & 0.803541 & $5.216538 * * *$ & $3.502180 * * *$ & 0.763255 \\
F-statistic & 118,980 & 118,980 & 118,980 & 118,980 \\
Total observations (balanced) & 1180 &
\end{tabular}

Note: This table presents the relationship between the level of the regional market integration (estimated using DCC-GARCH), crises, and excess return. Model I: $R_{i t}-R_{f t}=a+b \hat{\beta}_{i t}+\varepsilon_{i t}$ as equation (9), and model II: $R_{i t}-R_{f t}=a_{1}+b_{1} \hat{\beta}_{i t}+b_{2}$ Crisis $_{t}+b_{3}$ Crisis $_{t} * \hat{\beta}_{i t}+\varepsilon_{i t}$ As equation (10), the $1^{\text {st }}$ crisis period is the Asian financial crisis from 10/1997 to $12 / 1998$, and the subprime mortgage crisis is from $8 / 2007$, which was the initial fall in the stock markets due to the liquidity crisis, to $6 / 2009$. The $2^{\text {nd }}$ crisis period is the Asian financial crisis from 10/1997 to 12/1998, and the subprime mortgage crisis is from $9 / 2008$, which was when Lehman Brothers collapsed, to 6/2009. The Covid-19 period starts from the crash on March 2020 triggered by Covid19. All the models are estimated using pooled OLS with a fixed effect. *,**, and *** denote statistical significance at the $10 \%, 5 \%$, and $1 \%$ levels, respectively. 
Appendix D. List of Variables and Stock Market Index

\begin{tabular}{|c|c|c|c|}
\hline No & Country/Variable & Code & Stock Exchange/Index \\
\hline & \multicolumn{3}{|c|}{ Economic Territory/Domestic Markets } \\
\hline 1 & Indonesia & IDN & Jakarta Stock Exchange Composite Index \\
\hline 2 & China & $\mathrm{CHN}$ & Shanghai Stock Exchange Composite Index \\
\hline 3 & India & IND & S\&P BSE SENSEX Index \\
\hline 4 & Korea & KOR & Korea Stock Exchange KOSPI Index \\
\hline 5 & Malaysia & MYS & FTSE Bursa Malaysia KLCI Index \\
\hline 6 & Pakistan & PAK & Pakistan Karachi Index (100) \\
\hline 7 & Philippines & PHL & Philippines Stock Exchange (PSEi) Index \\
\hline 8 & Taiwan & TWN & Taiwan Stock Exchange Weighted Index \\
\hline 9 & Thailand & THA & Stock Exchange of Thailand (SET) Index \\
\hline 10 & Singapore & SGP & Straits Times Index (STI) \\
\hline 11 & Australia & AUS & Australian Stock Exchange All Ordinaries Index \\
\hline 12 & Hong Kong & HKG & Hong Kong Hang Seng Index (HSI) \\
\hline 13 & Japan & JPN & Tokyo Stock Exchange Tokyo Price Index (TOPIX) \\
\hline 14 & New Zeeland & NZL & S\&P/NZX All Index \\
\hline \multirow[t]{2}{*}{15} & United States of America & USA & New York Stock Exchange Composite Index \\
\hline & \multicolumn{3}{|c|}{ Morgan Stanley Capital International (MSCI) Index } \\
\hline 16 & Global Market & GLO & MSCI AC World Index \\
\hline \multirow[t]{2}{*}{17} & Regional Market & REG & MSCI AC Asia Pacific Index \\
\hline & Others & & \\
\hline 18 & Risk-Free & & US Treasury Bill 3 Month (Secondary Market Rate \\
\hline 19 & Exchange Rate & & Exchange Rate Base On USD \\
\hline
\end{tabular}

